\title{
A Critical Review of Luhmann's Social Systems Theory's Perspective on Mass Media and Social Media
}

\author{
Giray Gerim
}

\begin{abstract}
Niklas Luhmann's theory of social systems relies on a biology-based self-reproduction process called autopoiesis. The process occurs within operationally closed systems. Luhmann constructs his theory through adapting this approach to social ground with the assumption that a similar process and operationally closedness also exist in social systems. Alongside his works which examine fields such as economy, law, art, etc., Luhmann puts a special emphasis on the examination of mass media by applying this theory. However, in this article, it is argued that Luhmann's social systems theory today falls short of analyzing media efficiently despite that emphasis. The argument is endorsed in three main sections. In the first one, the social systems theory is explicated and discussed critically, and then its excessively abstract and theoretical structure is exposed. Secondly, the main lines of Luhmann's approach to mass media are given and a critical reading of that is carried out. In the last section, it is propounded that significant social media influence on today's mass media and increasing integration between the two cannot be sufficiently explained by the operationally closed systems approach in the social systems theory. This assertion is defended through an analysis of twitter as a platform of social media.
\end{abstract}

Keywords: social systems theory, Luhmann, mass media, social media, twitter.

Öz: Niklas Luhmann'ın sosyal sistemler kuramı biyoloji kökenli ve autopoiesis olarak adlandırılan bir kendini yeniden üretme sürecine dayanmaktadır. Bu süreç, operasyonel olarak kapalı sistemler içerisinde gerçekleşir. Luhmann, benzer kendini yeniden üretim ve operasyonel kapalılığın sosyal sistemlerde de mevcut olduğu kabulünden hareketle, bu biyolojik temelli işleyişi sosyal zemine uyarlayarak kendi sosyal sistemler kuramını oluşturur. Ekonomi, hukuk, sanat gibi çeşitli sosyal sistemleri bu kuram vasıtasıyla inceleyen Luhmann'ın, kuramın kitle medyasının analizinde kullanımına özel bir önem verdiği görülür. Buna rağmen, çalışmada Luhmann'ın sosyal sistemler kuramının bugün bu alanın verimli bir analizini sağlamada yetersiz kaldığı iddia edilmektedir. Bu iddia, üç ana aşamada temellendirilir. İlk aşamada sistemler kuramı eleştirel bir bakış açısıyla açıklanıp tartışılır ve kuramın uygulanmasını zorlaştıran fazla teorik ve soyut yapısı ortaya koyulur. İkinci aşamada, Luhmann'ın medyaya yaklaşımının ana hatları ve bunun eleştirisi verilir. Son aşamadaysa günümüz medyası üzerindeki kayda değer sosyal medya nüfuzu ve bu ikisi arasındaki artan iç içeliğin bugün artık kapalı sistemler yaklaşımıyla izahının mümkün olmadığı öne sürülür. Twitter örneği üzerinden girişilen çözümlemeyle bu iddia savunulur.

Anahtar Kelimeler: sosyal sistemler teorisi, Luhmann, medya, sosyal medya, twitter. 


\section{Introduction}

Niklas Luhmann has been one of the key figures in sociology in recent decades with his theory of social systems. His theory has been adapted to economy, religion, art, law, politics and some other social fields by him and other social scientists. Considering the systems in such social fields to be autonomous and operationally closed, Luhmann brought a new and -to some extent- innovative perspective to social analysis. However, as a grand theory, Luhmann's theory of social systems has deficiencies and gaps in such applications to various social fields due to its abstractness and complexity. In this work, it will be argued that the theory is inadequate to analyze and explain the operations of mass media and social media in connection with it since these two have become inseparable recently. Yet, there are two points which have to be explained at the beginning of the study. The first point is the usage of the concept 'mass media'. Luhmann uses this concept actually in a meaning almost corresponding to the mainstream news media. Since I discuss his theory and works as a big part of this study, I prefer to use the same words in order to preserve terminological unity. Secondly, it should be noted that the need to utter these two (mass media and social media) separately does not stem from a perspective which considers them in opposition. As can be seen later in this paper, it is a functionally useful separation which serves to analyze social media and its platforms by Luhmann's social systems theory.

When we review the works related to the application of Luhmann's systems theory to mass media, it is noticeable that most of them utilize it only partially by using and referring to some concepts and key components of the theory such as the systemic autonomy or the produced reality. As an example, Scholl and Weischenberg (1999) apply the theory to the journalism studies and elucidate the autonomy of journalists in their operations. In the study, it is pointed out that the autonomy journalists have does not mean that it has no contact with the environment. Rather, it refers to the selective relationships as a sub-system with its environment similar to the systems in Luhmann's theory. Hence, they argue that social systems theory can help to observe journalism in a more complex and adequate way. However, they just benefit from an aspect of the theory that corresponds to their research direction.

In Görke and School's study (2006), the systems theory's adaptation journalism is at the center and it is discussed that the reality represented or reflected by mass media is a media construction which depends on its own rules. That is why, it is impossible to criticize mass media for distortions of reality. There is a different reality and it cannot be accommodated with 'the reality' since journalism is an autonomous 
institution of society which is based on autonomous, self-organized processes. As can be seen, just a key concept of the theory is employed in the study as well.

In another study which can be considered close to this article in terms of its subject, Taekke (2011) analyzes Twitter by two theories; Latour's actor-network theory and Luhmann's systems theory. Taekke draws attention to the role of Twitter users in gathering people to demonstrations and making events visible to the Western mass media during 'the spring of North Africa'. He claims that Twitter as a new medium 'brings a new dimension to the structural coupling between the psychic and social level of systems formation. Nonetheless, he doesn't explain the processes of this coupling or what kind of relationship this important component of social media has with mass media.

What can be considered new and different from such works in this study is the attempt for a comprehensive critical review of the systems theory with regard to mass media and social media within an integrity. This review will be completed simply in three main parts. In the first part, I will address Luhmann's systems theory in general and try to discuss it through its source, main lines, scope and some criticism it has taken. In the second part, I will focus on the projection of the theory on mass media based on his own work in the related field. Furthermore, some critical reflections will be presented under subtitles in both parts in order to serve both the intended comprehensive critical reading and the foundation of the examination in the next part. Finally, in the last one, I will deal with social media -and twitter in particular- with reference to the systems theory and argue over its convenience in the analysis of this relatively new realm.

\section{Conceiving Luhmann's Systems Theory in General}

Luhmann's systems theory is based on and originally developed from the works of Maturana and Varela. The basic concept of their theory was autopoiesis which means self-(re)production. They argued that a living system was reproducing itself. Taking a cell as an example, what could be seen was that it was producing all of its elements with its own processes (Varela, Maturana \& Uribe, 1974). That meant they were operationally closed, and although the environment has an effect on a cell, it cannot be determinant in its operations. Another important point For Luhmann in this original theory was the definition of living systems as cognitive ones (Maturana \& Varela, 1980). They equalized life and cognition and put forward that the operations of an autopoietic system were its cognitions. What will be addressed in this paper as the distinction of self-reference and other references will 
be the outcome since cognition's being a self-referential through the autopoietic process. Last but not least, they introduced 'structural coupling' as a central aspect of autopoiesis. Its operations were being determined by the system absolutely; but the environment had the ability to trigger internal processes by perturbation or irritation. If significant environmental events or effects cause the system to adjust itself to the environment, it is a structural coupling since the system does not get any intervention directly but just operates inside for adjustment or adaptation.

Luhmann modified this originally biological theory and applied it to the field of social sciences. To start from the beginning of his adaptation, he asserts that autopoiesis can be found in non-biological systems as well if they demonstrate the features of self-reproduction. In this way, he exposes two other systems than the living systems which are examined by Varela and Maturana: psychic systems and social systems. All of these systems have their own way of reproduction and are actually separated by this criterion. Psychic system's reproduction is based on the consciousness and the basis of the reproduction of social systems is communication. Again with the same criterion and its outcomes, social systems and social research are divided into three sub-branches: societies, organizations and interactions (Seidl, 2004). Reproduction is what creates the differentiation of any system from its environment. This differentiation occurs via the system's interior complexity since this complexity forms the border of the system and assures its operative closure.

Seidl (2004, pp. 6-7) puts forth two profound modifications brought into the former concept of autopoiesis by Luhmann while molding his own concept. First of all, Varela and Maturana regarded the elements of their living systems relatively stable and something being replaced from time to time. However, Luhmann conceptualizes the elements as 'momentary events without any duration'. They occur and appear only once as points in time. This shift to reproduction of momentary events brings about a new understanding to autopoiesis that the system is urged to constant production and if it stops, the system disappears instantly. Aside from the temporal aspect, Luhmann changed the ontological comprehension of 'element' in 'his autopoiesis'. Outside or independently of the system, element has no meaning and it gains all its meaning through its relation to other elements and its function in the production. Thus, they are not 'ontologically pre-given' they don't possess such a meaning. This presumption provides an explanation of the relative insignificance of components in the systems theory.

Dealing with social systems, Luhmann (1986, p. 178) treats communication as the basic element of his theory in contrast to the sociological traditions in which either agents or actions are seen as the basis claiming that they are not compatible 
with autopoietic social systems. His concept of communication consists of three components: information, utterance and understanding. The last one can be considered novel and it has a key role in Luhmann's concept of communication. He states that communication is determined through the last. Nevertheless, by using understanding, his emphasis is not on the psychic dimension of communication. Although psychic systems can affect communication by irritating it and entailing structural coupling, they don't have any direct influence on communication. He prioritizes understanding within communication which can only exist through its relations with other communications according to its autopoietic structure. That is to say it needs the context of other communications to exist and to reproduce itself.

Despite regarding communications as the basis of autopoietic social systems, Luhmann (1995) admits that social systems construct their own image as a nexus of action within themselves. This kind of self-description actually elicits a simplification of the system. It rescues the system from the complexities of the entire communicative occurrence. Additionally, communication is not completed without the third component's -understanding-realizing; however, actions provide a clear-cut temporal relation (p. 168).

The last point to handle is the way Luhmann deals with the notion of the human being. The human being is not a systemic unity; but a conglomerate of organic and psychic systems. Psychic systems of this conglomerate are actually what matter to social systems. Both of those are operatively closed against each other, nevertheless they allow irritations from one another. He asserts that social systems treat human beings as systemic unities though they are not. Additionally, he defines that person is actually 'the social identification of a complex of expectations directed toward an individual human being' (Luhmann, 1995, p. 210).

\section{Some Critical Reflections on the Theory}

According to Luhmann (1995, pp. 168-169), there are some reasons why social systems construct their own image as a nexus of action within themselves. First of all, this kind of self-description elicits a simplification of the system. It rescues the system from the complexities of the entire communicative occurrence. Secondly, as it was said before, communications consist of three constituent components and are not completed without the third component, understanding; however, actions provide clear-cut temporal relations since they refer to one point in the time. Then, what is the point in handling societies only by communication which creates such hardships and difficulties as a basis while there are functionally smoother ones? Luhmann 
criticized some approaches due to their naivety and incapacity to represent or explain the social complexity (Khan, 2014, p. 6) and probably that is why he argued for the necessity of an approach at the same complexity level. Even so, in my view, to comprehend and operate in a complexity, you need something simpler as your tool. Mingers (2002, p. 420) contends that Luhmann's social theory consistently embodies a version of autopoiesis when compared to other social theories formed around autopoietic systems in spite of not being entirely consonant with Maturana's original formulation. Nevertheless, this achievement is reached at the expense of 'a very abstract and impoverished view of social processes and interactions'.

Another point from my perspective is the departing point of the theory. Undoubtedly, there are very significant contributions from Luhmann's systems theory to social analysis, for example, pointing out substantial distinctions -such as binary coding- in the working structures of different systems. Nonetheless, drawing parallels between living organisms and society/social structures is not a novel idea at all as we could observe also in classical works of the founding fathers of sociology such as Durkheim. Of course Luhmann exerted his modifications on the theory from its roots in Maturana and Varela's work; but it still looks like pushing society into your theory which you suddenly come up with from another discipline and clip the unfitting parts. In addition, grand theories with an allegation of explaining every aspect of society might have been popular once upon a time; however, today we are aware that societies have complex and enormous networks of interactions and there is no need for more complexities coming from the analytical methods themselves. In connection with the structure of the theory, in Luhmann's view, autopoiesis has no empirical explanatory value as a concept; but it has the potential to force other concepts into adaptation. Nonetheless, this attitude also can be questioned. According to Viskovatoff (1999, p. 494), Luhmann's theory has a deficiency arising out of autopoiesis. The approach of autopoietic systems cannot give an account of how biological cells produce their elements, so they re-produce themselves; but it only describes the situation. Just like that, Luhmann's systems theory describes that the social domain consists of communications but it is not able to explain or refer to an explanation how communications come about. Viskovatoff puts forward that Luhmann's system theory must do that in order to be an adequate scientific theory which means to be an empirical and explanatory theory as well. Poli (2010) finds it overstated and adds that almost all innovative frameworks need a long period of maturation before being ready for application. What I think is to support Luhmann's view would cause lots of problems in terms of scientific method since everybody could allege 'my theory holds the potential to force the others to adapt to it' without an elaboration of 'why' part (p. 41). 
As the last, it can be briefly stated that Luhmann's systems theory has a perspective placing people in a relatively unimportant position due to its conception of 'system'. As an early critique, Habermas (1987) rejects Luhmann's approach due to giving up emancipatory and humanistic values which have to be defended. Elder-Vass (2007) argues that Luhmann's model of systems denies 'the influence of the lower level properties on the behavior of the higher level system' when compared to the emergentist models of systems (p. 428). In his model, it is possible to neglect the effect of parts almost completely because of the priority of autopoiesis (p. 419). The defenders of the theory may claim that it lies on a descriptive ground for such purposes by analyzing society as it is; but again, a theory which discards human action to a large extent can only entail a strengthening functionality in our conceptualization of society rather than any progress toward emancipation. If a social theory alleges that human beings are not as important as system in terms of analysis, through which it claims to display the working mechanism of the system, it helps to construct a perception of society that diminishes the significance of individuals.

\section{The Systems Theory and Mass Media}

The systems theory puts a special emphasis on the construction of the reality and the key role of mass media in it. Luhmann addresses that role in The Reality of Mass Media (2000) and applies his general theory in this particular field -or -sub-system which is caused to emerge through the differentiation coming up with the technology of dissemination.

The book's main point is that mass media is self-referential and its functions are not determined by external factors, rather issued by a binary opposition such as information/non-information in the internal area of the system. By this way, the reality of mass media consists in its own operations (p. 3). In the other sub-systems, we observe the internal operations to grasp an understanding of theirs. However, Luhmann puts forward that the activity of mass media is not simply a sequence of operations but a sequence of observations; therefore, we have to observe their observing to understand the doubling of reality.

Before discussing the other key terms such as self-reference/other-reference and coding, we have to unpack the epistemological ground explaining Luhmann's approach to the notion of reality. Luhmann uses the basic premise of constructivist theories to attain his operational constructivism. According to it, 
“... cognitive systems are not in a position to distinguish between the conditions of existence of real objects and the conditions of their own knowledge because they have no access to such real objects other than through knowledge." (Luhmann, 2000, p. 5).

From this point forth, he claims that observing the cognitive operations of other systems gives us the possibility to see how they shape their knowledge by their own operations. That takes us to an operational constructivism which Luhmann opts for in the realm of epistemology. He regards reality as an internal correlation of the system's operations. For this reason, the question of the book is 'how does media construct reality?'; not 'how does media distort reality?' (p. 7). By asking the second, we would presuppose that there was an ontological and accessible reality out there, which would be an essentialist approach in contradiction with the mentioned epistemology. Therefore, Luhmann keeps the classical, everyday understandings of truth in terms of media reports out of the discussion stating such an evaluation is not possible for the mass daily flow of communications, except for some isolated cases. The code of true/untrue doesn't mean anything to the coding system of mass media (p. 36).

To comprehend how systems theory sees mass media, the distinction between the self-reference and other-reference is crucial. To put it simply, we can say that the first is the function of communication while the second is topic of communication. Despite its operational closure, mass media keeps its ties to society alive through topics which represent other-reference of communication. But of course, other-reference is processed by the operations of mass media which leads us to the coding of the system.

The entire system of mass media is based on the distinction of information and non-information. However, conceiving something as non-informative is necessary for the system in order not to see everything that comes to its way as information which would mean an incompetence in distinguishing itself from its environment (p. 17). In spite of denoting that it requires some closer analysis, Luhmann embraces Bateson's concept of information which is 'any difference which makes a difference in some later event' (p. 18). Another point to talk about, in his view, the most important characteristic of this information/non-information distinction is its relationship to time since information cannot be repeated. News can do that, but only with losing its information value. In addition, we can mention some exceptions such as advertisements, but what is seen there is just a repetition to make readers notice the value of the a product by repetition. 
Aside from coding, mass media's processing information possesses another crucial task for society. As we know payments of many has a role of differentiation in economy and 'generates the never-ending need to replace money spent'. So, Luhmann (2000) argues that 'the mass media produce the need to replace redundant information with new information'. In this way, society is prepared for surprises and disruptions; thus, mass media helps society's relationship with other function systems. With Luhmann's words, 'the mass media keep society on its toes' (pp. 20-22).

According to Luhmann (2000), the selection of information for dissemination as news or report is not random; it has some important criteria and individual organizations' role and freedom in it much less than critics often suppose. He contends that being based on surprise, conflicts, quantities, local relevance, norm violence, moral judgments and opinions on norm violations and special cases and some other phenomena constitute these criteria and he comments on all of them to clarify (pp. 28-34). Addressing news, Luhmann draws readers' attention to the fact that news and reports are not the same. While news (re)produces future uncertainties contrary to the general assumption that it helps with the general continuity in the world, reports provide the context of news and helps to give meaning to them. Their difference is conceived through their relationship to time as well. Reports are not dependent on daily events or situations while news is (p. 35).

\section{Some Criticism of the Luhmann's Approach to Mass Media}

As mentioned before, information is the key concept of Luhmann's mass media analysis. Therefore, the system is supposed to have an understanding of it. Luhmann thinks that there must be some rules within the system to treat something as informative or not. But what actually is information? He firstly uses Bateson's approach as mentioned before; but states that it requires some further analysis and contrary to it, he claims that by no means every difference makes a difference (Luhmann, 2000, p. 19). The usage of perception and language and through them, what remains in the memory for a long term makes the difference. When we observe the mass media, this approach doesn't work for most news - to illustrate, daily maganize and sports news- in my view, since we don't remember most of it one hour later. Additionally, just as Luhmann would admit, the system doesn't care about any change which information can create or cannot. That is why; I think we see an uncertainty to a large extent.

The second point I would like to discuss is the selection criteria for news. According to Luhmann (2000, p. 27), individuals or editorial boards are not as free as we 
suppose while there are selecting news. After this claim, he counts the criteria and elaborates on them across nearly eight pages. However, they look like a list such as 'how can you increase the sales figures of your newspapers?' rather than criteria. What is the reason behind such a list for Luhmann who is famous for not giving examples even after the most complicated theoretical parts in his works? It is hard to figure out. In addition, we can find every topic or situation we can think of, so this criteria is like putting no borders; everything which can be found interesting by society can be news to summarize it. In such a large frame, the human factor can play a very dominant role indeed. In addition, editorial boards usually make a selection from the news according to the informative or communicative value of a certain level and reserve the rest of their space or time for the news advocating the political groups close to them or enterprises, companies which belong to the same owner holding the newspaper or TV.

The last point to argue is Luhmann's naive perspective on TV. He believes that 'television has a limitation when broadcasting news, which has the effect of being a credibility bonus' (2000, pp. 39-40). He explains it with its being tied to the real time of news. Although 'With digitalization the array of possibilities for manipulation might be expected to increase'; he concludes with 'Television literally has 'no time' for manipulating the entire basal material'. Today, when we envisage the limits of computer based TV technologies; I believe what they can do in a time period less than one second would be enough for Luhmann to question his views about TV. In the related part, he uses another argument which sounds very ambiguous:

"At any rate, unlike words contradicting words, there is no sense in which pictures can be contradicted by pictures." (p. 40).

It is hard to understand in which meaning he uses the term contradiction; but pictures definitely can contradict each other in terms of meanings they give. However, the main point of the mass media perspective of Luhmann's systems theory is not manipulation, it is construction. Thus, I prefer not to go deep into it. The point here is to show developing technology can urge theories to modify themselves or their approach to specific fields according to new conditions, and we will have the chance to observe it in the third part as well.

\section{The Systems Theory's Convenience for Social Media: the Example of Twitter}

It can be argued that Luhmann's systems theory cannot be applied to social media for the reasons that Luhmann couldn't witness the emergence and rise of social media and therefore his theory doesn't have an extension to handle social media. 
Nevertheless, first of all, there are researchers who disregard this and apply the theory to their works on social media, or at least they claim so (Taekke, 2011; Wigley, 2011). Secondly, our age's mass media cannot be analyzed separately from social media regarding the high level of interaction between the two of them. That is why I will try to attempt to see the matter closer with the help of the 'twitter' example.

In the last decade, social media has risen as a very significant information source. This situation triggered scientific research focusing on the credibility of information coming from social media (Westerman, Spence \& Van der Heide, 2014) or developing tools for journalists to search for and assess the sources in social media especially for breaking news (Diakopoulos, Choudhury \& Naaman, 2012).

Twitter as a special example demonstrates how news, information, comments, and personal details flow out from social media as a mix rather than an established set. This structure forms the conditions for other agents than journalists to get involved in the production of journalistic products, particularly news (Vis, 2013, p. 29). It is believed that twitter has brought countless new opportunities from evaluating ordinary people's attitudes to events, to public sentiments about politicians and their performances which was so indirect to observe before social media (Broersma \& Graham, 2012, pp. 12-13). To explain the service, it is based on sharing your messages with a maximum of 140 characters; people who are interested in your messages follow you or vice versa; with using hashtags (a kind of label made with a '\#' sign) you label a theme or content to make them easier to find. You can send everything you think or feel about something as a post; moreover, you can add links to refer to the other kinds of media such as online newspapers and personal blogs. Its structure rendering instant information possible to share among people or groups has made twitter a rising social phenomenon for new social events.

However, the relationship between the mass media and twitter is seen problematic to some extent since the borders are not very clear. Wigley (2011) handles this relationship and attempts to show that twitter is exhibiting a systemic autonomy. He uses two cases to prove the operational closure of Twitter as a system. In the first one, Elliot Madison informs protesters of the movements of police with the help of police radio scanners through twitter posts during the G20 summit in Pittsburgh, Pennsylvania in 2009. In the second one, in 2010, Paul Chambers post a tweet and says 'Crap! Robin Hood Airport is closed, you've got a week and a bit to get your shit together otherwise I'm blowing the airport sky high!'. Both of them are arrested, judged and got punishment. Wigley contends that the main problem with these cases is the different meaning in each cases. In the first one, twitter is treated as mass media and it causes a different interpretation than it would within the borders of twitter. In the second, it is again -maybe- a joke being interpreted 
as a serious threat because it is taken out of its boundaries. Those are, according to Wigley (2011, p. 16), 'compelling evidence that twitter fulfills the conditions of systemic formation in that it is operationally closed and is autopoietic in nature'. As a result, he believes that a deeper systemic analysis with employing concepts such as medium and form, coding, function and the others would bring about a more complete understanding of the role twitter plays in society.

What Wigley does looks like an overstatement if we look into the events or situations separately. In the first one, he claims that Madison's using twitter is perceived as using mass media and judged accordingly. Actually, when we consider its power to touch the masses, it can be seen as a branch of mass media in that respect; there is no mistake in this consideration. Even the giants of mass media have to use twitter accounts to reach the masses today; so, again, nothing is unusual about this aspect. In the second one, it is all about the context of what you say; out of context, everything has a risk of being misinterpreted. However, we call it 'context', not 'system'. Calling every different context 'system' cannot bring about a good outcome, it just causes more confusion.

Another issue, almost all the premises of the systems theory is uncertain in twitter. Everybody shares everything, what is informative/non-informative is very hard to figure out. The boundaries are not definite since web links are used to refer to anything out of twitter. There are no stable transformation mechanisms between twitter and mass media and both of them make use of everything as post or news respectively. Even the basic 140 characters rule is not meaningful; someone can even write a novel with serial tweets. However, as a result of our age's individuality, a very significant amount of the population of the world has social media accounts -such as twitter- and they catch the day in social media. In other words, individual social media accounts have a very significant intercessor role to access the news on various platforms of mass media as Mitchell and Guskin (2013) shows successfully. Moreover, as a result of an empirical study, Holton et all. (2015) reveals that active users of social media platforms are also active in content creation processes of news and socal media accounts contribute to media agenda-building and agenda-setting to a large extent by their content (comments, statements, photos, opinions, etc.) flowing to the news media (Skogerbø, Bruns, Quodling \& Ingebretsen , 2016) while the other way around can be considered right, too (Rogstad, 2016). Hence, any theory which has a claim to offer a comprehensive analysis of today's new media has to be able to explain the structure and operations of social media as well. Nevertheless, social media in general and Twitter as the example we examined doesn't reflect the operational boundaries and systemic autonomy which are put forward as the significant features of closed systems in Luhmann's systems theory. 


\section{Conclusion}

I followed a direction from general to particular in the outline of my paper as can be seen. The purpose was to question the theoretical ground first and then to head towards the applications of this ground. Firstly, I made a critical reading on Luhmann's theory of systems in general and I expected this reading to be helpful to analyze his approach to mass media through the systems theory. And lastly, I tried to draw attention to a relatively neglected branch of media and to discuss it with the help of using twitter as an example. I discussed about how the theory falls short in analyzing and explaining mass media and social media today since these are in an intense interaction with one another or more or less integrated with each other.

Vanderstraeten (2002) asserts that Luhmann's work can be delineated as a critical evaluation and modification of the works of sociology's founding fathers although Luhman himself severely criticizes the researchers who return to the classical works to criticize, dissect and re-combine them (pp. 77-78). What I attempt to do here is similar to what Luhmann does to some extent since he can be regarded as a prominent figure in modern sociology. The ultimate goal in this study is not simply to discredit a theory which has brought significant analytical facilities and opportunities into social sciences with its new perspective. It is just to emphasize the significance of being critical of such grand theories which claim to explain various dimensions of social reality. We can refer to any theory for help in analyzing any social event, situation, or phenomenon; but it does not mean that we have to apply the theory entirely to reach a solution. We can take many aspects and concepts from any theory to use and to combine with each other; however, forcing all aspects of a single theory into a related case may result in wrong outcomes as it is demonstrated in twitter example; especially in grand theories such as Luhmann's systems theory.

\section{References}

Broersma, M., \& Graham, T. (2012). Social Media as Beat: Tweets as a News Source during the 2010 British and Dutch Elections. Journalism Practice, 6(3), 403-419.

Diakopoulos, N., De Choudhury, M., \& Naaman, M. (2012). Finding and Assessing Social Media Information Sources in the Context of Journalism. In Proceedings of the SIGCHI Conference on Human Factors in Computing Systems (pp. 2451-2460). ACM.

Elder-Vass, D. (2007). Luhmann and Emergentism: Competing Paradigms for Social Systems Theory? Philosophy of the Social Sciences, 37(4), 408-432.

Görke, A., \& Scholl, A. (2006). Niklas Luhmann's Theory of Social Systems and Journalism Research. Journalism Studies, 7(4), 644-655. 


\section{The Journal of Humanity and Society}

Habermas, J. (1987). The Philosophical Discourse of Modernity (F. G. Lawrence, Trans.) Cambridge: MIT Press.

Holton, A. E., Coddington, M., Lewis, S. C., \& De Zuniga, H. G. (2015). Reciprocity and the News: The Role of Personal and Social Media Reciprocity in News Creation and Consumption. International Journal of Communication, 9, 22.

Khan, S. R. (2014). "Humans Cannot Communicate"-Unravelling the Mental Knots of Niklas Luhmann. Contemporary Sociology: A Journal of Reviews, 43(1), 49-55.

Luhmann, N. (1986). The Autopoiesis of Social Systems. In F.Geyer \& J. van der Zouwen (Eds.), Sociocybernetic Paradoxes: Observation, Control and Evolution of Self-Steering Systems (pp. 172-192). London: Sage Publications.

Luhmann, N. (1995). Social Systems (J. Bednarz \& D. Baecker, Trans.). Stanford, CA: Stanford University Press.

Luhmann, N. (2000). The Reality of the Mass Media (K. Cross, Trans.). Stanford, CA: Stanford University Press.

Maturana, H. \& Varela, F. (1980). Autopoiesis and Cognition: The Realization of the Living. Dordrecht: Reidel Publishing.

Mingers, J. (2002). Can Social Systems Be Autopoietic? Assessing Luhmann's Social Theory. The Sociological Review, 50(2), 278-299.

Mitchell, A., \& Guskin, E. (2013). Twitter news consumers: Young, mobile and educated. Pew Research Journalism Project, November, 4.

Poli, R. (2010). The Complexity of Self-reference. A Critical Evaluation of Luhmann's Theory of Social Systems. Dipartimento di Sociologia e Ricerca Sociela, Quaderno 50.

Rogstad, I. (2016). Is Twitter just rehashing? Intermedia agenda setting between Twitter and mainstream media. Journal of Information Technology \& Politics, 13(2), 142-158.

Scholl, A., \& Weischenberg, S. (1999). Autonomy in Journalism: How It is Related to Attitudes and Behavior of Media Professionals. Web Journal of Mass Communication Research, 2(4). Retrieved from https://www.scripps. ohiou.edu/wjmcr/vol02/2-4a.htm.

Seidl, D. (2004). Luhmann's Theory of Autopoietic Social Systems. Ludwig-Maximilians-Universität München-Munich School of Management. Retrieved from http://www.zfog.bwl.uni-muenchen.de/files/mitarbeiter/paper2004_2.pdf.

Skogerbø, E., Bruns, A., Quodling, A., \& Ingebretsen, T. (2016). Agenda-setting revisited: Social media and sourcing in mainstream journalism. The Routledge Companion to Social Media and Politics, 104-120.

Tække, J. (2011). Structural Coupling and Translation-Twitter observed as Communication Medium and Nonhuman Actor. In conference paper to 'Power and Participation: The 25th Conference of the Nordic Sociological Association in Oslo'.

Vanderstraeten, R. (2002). Parsons, Luhmann and the Theorem of Double Contingency. Journal of Classical Sociology, 2(1), 77-92.

Varela, F., Maturana, H. and Uribe, R. (1974). Autopoiesis: The Organization of Living Systems, Its Characterization and a Model. Biosystems, 5, 187-96.

Vis, F. (2013). Twitter as a Reporting tool for Breaking News: Journalists Tweeting the 2011 UK Riots. Digital Journalism, 1(1), 27-47.

Viskovatoff, A. (1999). Foundations of Niklas Luhmann's Theory of Social Systems. Philosophy of the Social Sciences, 29(4), 481-516.

Westerman, D., Spence, P. R., \& Van Der Heide, B. (2014). Social Media as Information Source: Recency of Updates and Credibility of Information. Journal of Computer-Mediated Communication, 19(2), 171-183.

Wigley, R. (2011). Novel Noise? A Systems-theoretical Approach to Twitter. Cultural Policy, Criticism and Management Research 5. Retrieved from https://culturalpolicyjournal.wordpress.com/past-issues/issue-no-5/\%EF\%BB\%BFnovel-noise/. 